\title{
10 YEARS AFTER: THE IMPACT OF EU ACCESSION ON THE SLOVENIAN-AUSTRIAN CROSS-BORDER AREA IN POMURJE REGION
}

\author{
Naja Marot ${ }^{1}$
}

Received 15 February 2013; Accepted 12 April 2013

\begin{abstract}
The articles derives from the research about potential socio-economic and landscape changes EU accession would bring for Slovenia as perceived by the local population in the selected region. The author analyzed which of the predicted changes have been also mirrored in the landscape and how removing the borders improved not just the quality but also the perception of the landscape. Special attention was given to the joined cross-border initiatives which aim at improving the local and regional economic conditions, advancing the agricultural practice and better environment in the region. On one hand, the accession has been along with the opportunities EU initiatives offer accepted as the positive change in the region, on the other it has requested several, sometimes unwanted adaptations in the local communities in order to comply with the EU policies and legislation.
\end{abstract}

Keywords: cross-border co-operation, cultural landscape, CBC Slovenia-Austria, regional development, public participation

Povzetek: Članek temelji na raziskavi, ki je bila opravljena pred priključitvijo Slovenije Evropski uniji z namenom, da se ugotovi, kako lokalni prebivalci dojemajo in predvidevajo družbeno-gospodarske posledice in spremembe v kulturni krajini, ki jih bo ta politična sprememba prinesla. Avtorica je analizirala, kako se napovedane spremembe odražajo v prostoru 10 let kasneje in kako je odprtje metje izboljšalo kakovost in tudi dojemanje krajine. Slednja se je spremenila zlasti zaradi prekomejnih CBC iniciativ, katerih namen je izboljšanje lokalnega in regionalnega gospodarstva, napredek kmetijstva in večja trajnost regije. Zaključimo lahko, da je priključitev Evropski uniji regiji prinesla pozitivne spremembe, vendar se je potrebno zavedati tudi nezaželenih posledic, ki nastanejo zaradi prilagajanja lokalnih skupnosti evropskim politikam.

Ključne besede: prekomejno sodelovanje, kulturna krajina, CBC Slovenija-Avstrija, regionalni razvoj, sodelovanje javnosti

\section{Introduction}

Slovenia entered European Union in 2004 and was then from the following year also eligible to benefit from the EU Interreg III programme co-financed by the European Regional Development

\footnotetext{
${ }^{1}$ Dr. Naja Marot, Urban Planning Institute of the Republic of Slovenia, Trnovski pristan 2, 1000 Ljubljana, e-mail: naja.marot@uirs.si
} 
Fund. This programme has been firstly introduced in the period 1989-1993 to support the less developed EU regions including border areas by the principle of a more balanced European territory (Medeiros, 2009) or as stated in the next programme: "a transfrontier cooperation in economic development and for the preparation of the border regions to make the most of the opportunities and challenges of increasing European integration" (CEC, 1994). This process should primarily be aimed at restructuring and intensifying the interregional economic relations (Krätke, 2002) or as Holly et al. (2003) argued equalize asymmetries between the current and future EU members. According to the programme cross-border areas have been granted attention on the basis of two geographical facts: border areas account for some $60 \%$ of the EU area and $41 \%$ of the EU population; and because of specific historical, economic, cultural and administrative factors, which have occurred due to the border location effect. Among different definitions of cross-border co-operation, shorter CBC (Perkmann, 2003; Raich, 1995) we adopted the Schmitt-Egner (1998, p. 63) understanding by the cross-border co-operation is defined as "cross-border interaction between neighbouring regions for the preservation, governance and development of their common living space; without the involvement of their central authorities". This institutional cooperation and support, as well as communication and infrastructure are above the most valued benefits of CBC as reported by EU cohesion reports (CEC, 2012) and other authors (Ladysz, 2006; Potocnik, 2001; Schabhüser, 1993; Panteia, 2010), and as already underlined in European Spatial Development Perspectives (CEC, 1999). Further, Ladysz (2006) argues that EU co-operation is required in terms of guidance and financial assistance to achieve landscape transformation, e.g. joint water source management, the improvement of regional public and main transport networks, and above all, the landscape development and environmental protection policy for ecologically sensitive areas. Not that the CBC establishes new institutional arrangements but it also physically cuts across national borders and enables to follow environmental and physical geographical limitations in protecting or developing the common landscape, else divided by the national borders (ESPON, 2006). In INTERREG III projects the most popular themes were growth, employment and competitiveness ( $20 \%$ of funding), while the environment and quality of life came in with $17 \%$ of funds expenditure (ESPON, 2007). The evaluation of the programme 2000-2006 showed that interventions focussed mostly on enhancing the socio-economic development of the respective co-operation areas, further the case studies showed that there were substantial direct effects on the socio-economic and sustainable development of the cross-border area (Panteia, 2010).

In the period 2007-2013 Interreg IIIA - the goal of cross-border economic, social and environment activities delivered on the basis of comprehensive strategies for the sustainable territorial development - is financially the most supported one, since $74 \%$ (5.6 billion EUR) of the funds have been granted to it of which the Slovenian-Austrian programme gained 74.2 million euro (CBC SI-AT, 2012c). What is specific to the Slovenian territory, is that almost all - eleven out of twelve - development regions can benefit from at least one CBC programme which implies that $\mathrm{CBC}$ instrument represents one of the major development instruments. Besides that in the pre-accession period Slovenia was also entitled to the means of Phare, ISPA, TACIS and SAPARD (Potocnik, 2001). Until now the CBC has been investigated by different fields, but most of the researchers have focused on the normative added value of the programme (Perkmann, 2003; Gonin, 1994) or as in the works of economic geographers like Huber (2003) focused on the impact of borders on the choice of location of firms in border regions (Van Houtum, 1998). On the contrary to the normative approach and the several approaches for measuring landscape changes (Keisteri, 1990; Antrop, 1998; Naveh, 2000), this article has shifted the focus more towards the applicative dimension studied on actual cases in the Slovenian-Austria CBC programme. The area included in the programme covers six Slovenian NUTSIII regions ${ }^{2}$ and nine Austrian NUTSIII regions ${ }^{3}$ (see Figure 1). More into detail, the research has engaged with the small area of four selected municipalities in Pomurska and South Styria which in both countries belong to the deprived, lagging behind regions. That confirms Krätke (2002) hypothesis that border regions are frequently taken as a type of region with a peripheral position in terms of particular structural weaknesses. By such a choice we

\footnotetext{
${ }^{2}$ Gorenjska, Savinjska, Koroška, Podravska, Osrednjeslovenska and Pomurska region.

3 Oststeiermark, West- and Südsteiermark, Graz, Obersteiermark-Ost, Obersteiermark-West, Klagenfurt - Villach, Unterkärnten, Oberkärnten and Südburgenland.
} 
wanted to bring forward also the small, local level territorial units which are most directly influenced by the CBC (Panteia, 2010; Holly et al., 2003). As the numbers later indicate selected local communities can be identified as the small size towns which lay in the vicinity of larger city areas: Maribor in Slovenia and Graz in Austria and present the other pole of the otherwise developed urban centres.

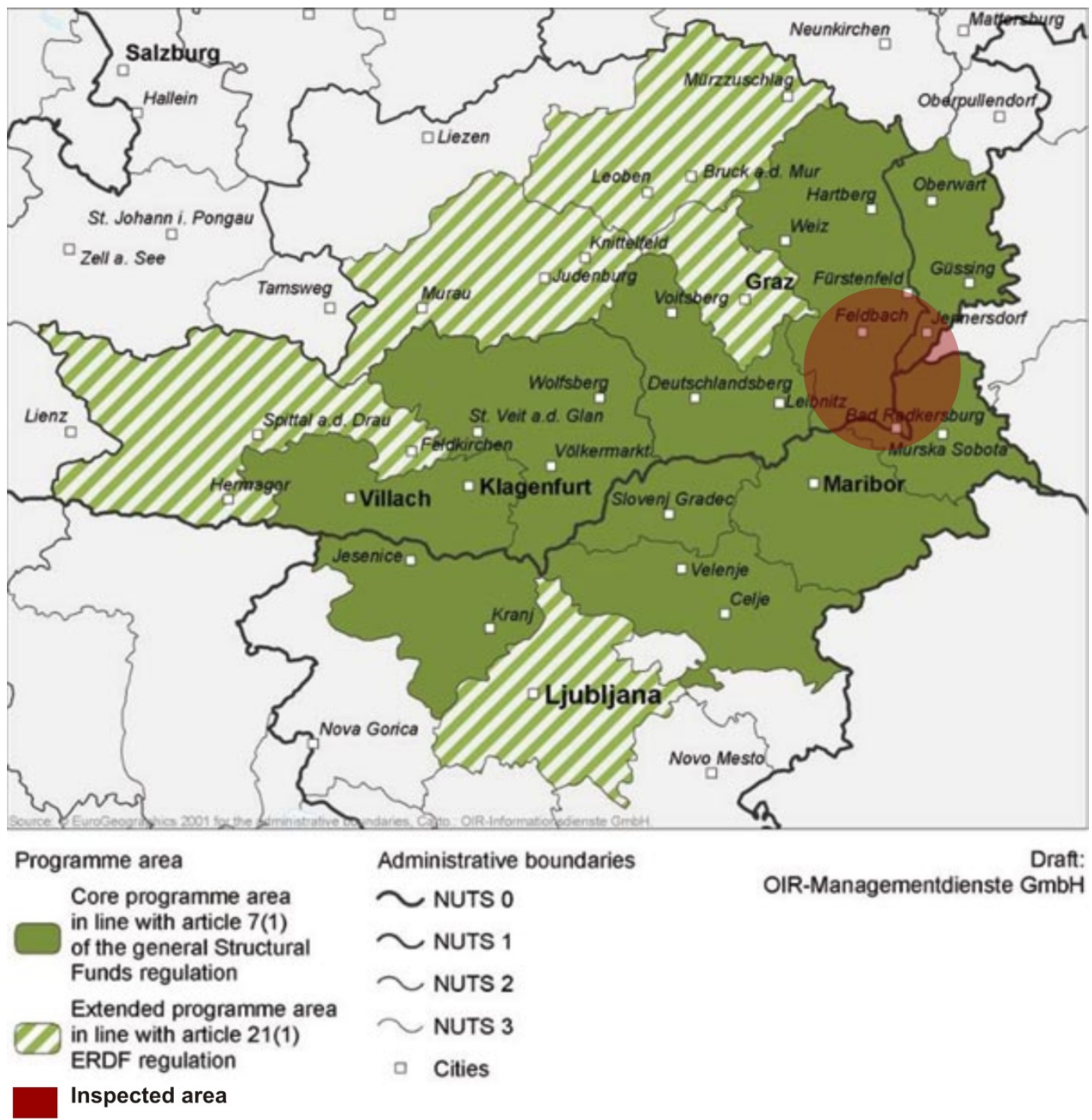

Fig 1. Area of Slovenian-Austrian CBC. (CBC SI-AT, 2012)

The core interest of the article is to explore the landscape changes as might have been induced by Slovenia joining EU and along that the footprints that the CBC programme has left in the territory. The landscape focus has been selected because Central and Eastern European countries have witnessed and experienced a set of political changes, thus socio-economic formations in the $20^{\text {th }}$ century that caused profound and widespread changes in the landscape functions, forms, meanings and perception (Ladysz, 2006). Furthermore, these changes were spurred after enlargement of EU which also resulted in a change of land use patterns or, for example, agricultural practices (Urbanc et al., 2004) which had already been significantly moderated in the socialistic socio-economic system (Potocnik, 2001). Since important dimension of the landscape changes is the public, the local population was addressed 10 years ago in order to predict the potential changes on both sides of the borders in general and regarding the specific topics like job market, quality of life, landscape and mentality (Holly et al., 2003). To check whether their predictions were right and whether expressed fears about the enlarged EU were legitimate we checked what has happened/is happening in the region 
10 years after and how the CBC programme or utilization of other EU funds have contributed to the (sustainable) development of the landscape.

\section{Methodology}

\subsection{Concept of landscape}

Landscape is a very general term and the word can be regarded as synonym for the region describing a territory of different size defined by common characteristics. Here we concentrate more on the landscape as understood by the German-Russian school in a narrower dimension of a physical landscape or cultural landscape, a territory of which existence and preservation is conditioned by human activity (Antrop, 1998, 2005). In line with this is also the legal definition of the landscape as similarly introduced both by the Slovenian Spatial Planning Act (2007) and by the Spatial Development Strategy of Slovenia (Ministry of the Environment, 2004) stating that the landscape is "part of the physical space, characterized by a prevailing presence of natural components, and is the result of the interaction and influence of natural and human activity" (Article 2, Spatial Planning Act, 2007). The strategy further delineates the landscape development as "the rearrangement, restoration or preservation of spatial proportions in landscape due to the placement of new activities or modernisation of existing ones, while taking into consideration the actual natural and cultural landscape features" (Ministry of the Environment, 2004, 10). As Palang et al. (2000) and Antrop (1998) argue the landscape and its elements constantly change due to the natural and human steered processes.

In order to maintain the qualities and individuality of the landscape, the national strategy introduced the goals and measures tailored to each landscape region. The border regions have been recognized as areas with special potentials and problems in which conditions shall be provided for high quality employment and for achieving the development level of adjacent areas in neighbouring countries, particularly in areas with development problems (Ministry of the Environment, 2004). Also, Slovenia has planned to endeavour integration and formation of cross-border regions with joint development programmes. Further on, Slovenia signed the European Landscape Convention on March $7^{\text {th }} 2001$ and officially ratified it in year 2003 . The convention besides the preservation of physical characteristics recognizes important role of the landscape in guaranteeing the quality of life, as the public interest in cultural, ecological and social aspect, as important for the economy and as one of the elements establishing and maintaining the European identity (CE, 2000). The value of the later can be especially altered in the case of political change which not only influence the physical characteristics, e.g. application/removal of the border but also influences people's perception of them. Additionally, change in power and political regime might bring conversion in society's values followed by disintegration, disappearance of landscape elements which have now assigned new functions and meanings (Urbanc et al. 2004). One of the latest politically induced changes in perceiving the landscape was through the introduction of spatial sustainability which entails demographic, economic, social, environmental, natural and cultural aspects and aims at establishing equilibrium among these different aspects. Ladysz (2006) especially exposed that to meet the goals of sustainability a landscape transformed under one political regime, in this case socialistic one, must integrate under another, European one which has now been the case in Slovenian-Austrian territory.

\subsection{Short introduction into the region/selected municipalities}

Region included in the analysis has always been a vivid territory, both in the historical and political aspect. In Slovenia the Prekmurje region is circled from three sides with different speaking population and three different cultures therefore the borders have in the past always shaped the local culture, life of the people, mentality and economic development. Important milestones in the local history were entering the country of Serbs, Croats and Slovenians, The Trianon peaceful treaty which divided Prekmurje region between three states (Hungary, Austria and Slovenia). While one part was suffering from the negative economic impacts caused by the application of the Iron curtain in 1948; the other side, Slovenian-Austrian border, was kept opened until 1960 and quite easily crossable. Hence, the western Prekmurje to which also 
the case study area belongs has already been experiencing a cross border exchange that after Slovenia joining EU just continued and empowered (Zupančič, 2003, 2009; Klemenčič, 1992).

For the case study we have selected the so-called Radgona-Corner which has been in history significantly influenced by the above mentioned processes and in both countries now presents area lagging behind (Tropper, 2009). In Slovenia it includes a smaller part of Pomurska development region - municipalities of Gornja Radgona and Cankova - and in Austria municipalities Bad Radkersburg and Feldbach, both located in the south-eastern part of the Styria. This area has been selected on the basis of common history, the similarities of twin cities in physical characteristics, e.g. flat Pannonian land circumstanced by the hillocks which are cultivated by the vineyards, and because of the previously performed survey. The localities are small in population (Gornja Radgona 8,617 inhabitants, Feldbach 4,643, Bad Radkersburg 1,326 and Cankova 1,896; SORS, 2012a; SA, 2012) and in size (see Table 1).

The classification of the type of the economically weak cross-border region - in comparison to the strong interior regional economic centres (Krätke, 2002) - corresponds to the economic situation including the high unemployment level - in Slovenia significantly higher -, and low GDP which is below the national average. In regard to the historical and political development, the region has always been the outmigration region, both in terms of migration workers and the permanent emigrants (Zupančič, 2009; Damijan, 2012). In both municipalities of Gornja Radgona and Bad Radkersburg tourism plays an important role in the local economy, the demographics, including the ageing (ageing index of Cankova is 128, Gornja Radgona 136, Bad Radkersberg 248), low attained educational level (40\% of people older than 15 years finished only grammar school or less) and poor high education opportunities do not speak in favour of positive development options in the region. Evident is also the duality between the developed city regional centres and the other, partially suburbanized, partially agricultural area in which selected municipalities are located. The duality is conditioned with the distance to the centre locations Graz and Maribor: as for example the northern-east communities of Feldbach and Gnas experience the rise of population, working places, built area and the commuters share, on the contrary in south-eastern, less accessible, part of Styria the number of population and jobs is steadily decreasing and the agrarian rate in the district of Radkersburg is still the highest in the State of Styria (Tropper, 2009). Regarding to that, the role of Murska Sobota as the strong regional centre has been compromised by the closure of industries, e.g. textile industry, and by the construction of the highway which increased the importance of else more distant centres of higher importance.

\begin{tabular}{|c|c|c|c|c|c|c|}
\hline & $\begin{array}{l}\text { Cankova } \\
\text { (SI) }\end{array}$ & $\begin{array}{l}\text { Gornja } \\
\text { Radgona } \\
\text { (SI) }\end{array}$ & $\begin{array}{l}\text { Bad } \\
\text { Radkersburg } \\
\text { (AT) }\end{array}$ & $\begin{array}{l}\text { Feldbac } \\
\text { h (AT) }\end{array}$ & Slovenia & Austria \\
\hline Population* ${ }^{*}$ & 1,896 & 8,617 & 1,326 & 4,643 & $2,056,262$ & $8,443,018$ \\
\hline Size $\left(\mathrm{km}^{2}\right)$ & 31 & 75 & 2.2 & 3.2 & 20,273 & $83,878.99$ \\
\hline Density & 61 & 115 & 614 & 1446 & 101.4 & 100.7 \\
\hline Natural growth (2011) & 0.5 & -3.2 & -24.8 & 0.65 & 1.6 & 0.19 \\
\hline Net migration (2011) & 1.1 & 4.8 & 0.75 & 4.95 & 1.0 & 4.2 \\
\hline $\begin{array}{l}\text { Total increase of } \\
\text { population (2011) }\end{array}$ & 1.6 & 1.6 & -24.05 & 5.6 & 2.6 & 4.39 \\
\hline Average age & 42.8 & 42.9 & 1 & 1 & 42 & 7 \\
\hline Aging index & 127.8 & 135.9 & 248 & 98.9 & 118 & 123 \\
\hline $\begin{array}{l}\% \text { of youth (SI } 0-14 \text {, } \\
\text { AT } 0-20)\end{array}$ & 12.3 & 12.9 & 12.3 & 19.0 & 14.4 & 14.5 \\
\hline$\%$ of elderly $(65+)$ & 15.8 & 17.5 & 30.6 & 18.8 & 17 & 17.8 \\
\hline Unemployment & 18.8 & 13.8 & $\begin{array}{r}3.9 \\
(2009)\end{array}$ & $\begin{array}{r}7.0 \\
(2009)\end{array}$ & 12.1 & $\begin{array}{r}4,1 \\
(2011)\end{array}$ \\
\hline Average net salary & 923.98 & 878.74 & 1 & 1 & 986.81 & \\
\hline
\end{tabular}

Tab 1. Basic statistics of case-study municipalities. (SORS, 2012a; Landesstatistik Steiermark, 2013; Statistics Austria, 2013.)

* Data is for the year 2012 if not stated otherwise. 
The spatial potential of the municipalities is a shared development source. The region on both sides of the border is rich in natural and cultural heritage, deriving from the river Mura, Landscape park Goričko, Klöch volcanic region and the rich history of the Bad Radkersburg town. In the whole Pomurska region $61 \%$ of area is protected under Natura2000 $\left(816.2 \mathrm{~km}^{2}\right)-$ Cankova $27.8 \%$ and Gornja Radgona $14,6 \%$ - and other regimes of protection have been applied to the individual areas recording to the national nature protection law. These areas on both side of the border present a huge opportunity both for the development of recreational and sustainable tourism (Vintar Mally et al., 2009) as are on the other hand vulnerable to the impacts of economic activity.

\subsection{Data collection and analysis}

The article derives from the research performed in a joint Slovenian-Austrian consortium which 10 years ago inspected the expectations, values, fears and public views on how the Slovenian accession to the EU would influence the cross-border area of the municipalities Gornja Radgona, Cankova, Bad Radkersburg and Feldbach. Research performed in the period 2000 and 2002 was financed by the Austrian Federal Ministry for education, science and culture (Regional Consulting Vienna, 2002). The main attention was dedicated to the relationship between socio-economic challenges of the accession and the past and the future landscape changes, as perceived by the public; topics such as gender mainstreaming, cross-border processes and definition of functional regions were also covered.

Research work was structured by topics to which different methods were applied, e.g. the topics of gender mainstreaming was addressed mainly through the literature review and expert talks, all with the purpose to answer the questions like How the functions of the territory change? How does the social environment change and which landscape-ecological changes is it possible to notice. In this article we are elaborating the results of the public participation process in which the opinions on the landscape and regional future development were gathered.

Public participation process consisted of multiple steps: analysis, in which the statistical description of the involved region was followed by the workshops and interviews in order to collect also information on institutional framework and spatial processes not captured necessarily by the statistics. First workshop was organized in the beginning of the project to disseminate the project idea and procedure for public participation, the second one was focused on preparation of scenarios and of "telling the future stories" by which people's ideas about the future development are grasped. Workshops were organized in Slovenia and Austria, altogether around 300 local and regional stakeholders participated among who were locals, politicians, policy makers, teachers, representatives of regional institutions and companies, state employees. General public had the opportunity to participate through the interviews which is a commonly used method in CBC research (Perkmann, 2003; Holly et al., 2003). In Slovenia interviews with 275 inhabitants of either Gornja Radgona or Cankova were done in person, while in Austria, 265 phone interviews were performed which were intended for evaluation of the development processes that were in place due to the Slovenian EU accession and were predicted to happen, such as job market changes, education, culture provision, quality of life, tourism, agriculture, transport and potential future projects. In the group of participants there was the same share of women and men according to the gender mainstreaming principle, and allocation of the respondents in 15-year-age groups, staring 15 year up was equilibrated as well. Especially landscape changes were illustrated with the method called "the window into the development of cultural landscape" which included investigation of the micro level territorial unit in historical, current and future prospect (Das Mur Projekt, 2006; Regional Consulting Vienna, 2002).

Ten years later, when Slovenia has already been enjoying the benefits of EU, no funds were granted for a repetition of the research, therefore the comparison was done on the basis of statistical data, analysis of policy documents (operational programme of CBC, regional development programme), secondary resources for landscape changes and policy documents concerning the regions and other relevant studies. A special attention has been given to the $\mathrm{CBC}$ projects that have invested into the improvements of landscape and tourism and agriculture as economic activities, most connected to the landscape preservation and change. 
The main purpose was to find out whether the expectation and fears of the respondents regarding the landscape changes and regional development expressed in the research can be confirmed right or wrong. This tells us to which extent information gathered in public participation processes can help the planners in predicting and planning for the future.

\section{Results}

\subsection{General impacts of entering EU on the selected areas}

The original research firstly inquired among participants about their general opinion on the region and Slovenian accession to the EU. On what was positive in the region both participants agreed on landscape and social infrastructure in Feldbach and Gornja Radgona, else Austrians exposed peace, climate and high life standard while Slovenians mentioned the people and the community, nature and environment. The list of negative characteristics was the same on both sides and included the transport infrastructure, loneliness and periphery, situation on the job market, the Austrians mentioned also the foreigners. When inquired on differences in mentality of the people, Slovenians answered more affirmative (around $60 \%$ answered yes) than Austrians (35\%) but regarding the Slovenian accession the picture was the opposite since more Austrian than Slovenians felt positive about it. Interestingly, the largest difference was between the two Slovenians communities: the inhabitants of Gornja Radgona were fare less convinced about the EU than inhabitants of a more rural Cankova.

Next question focused directly on the CBC region and its pros and cons (see Table 2). People from both sides agreed that such an area presents a pool for co-operation and openness to the neighbours and among benefits listed also possibilities for cheaper shopping. Further, the Austrians mentioned high quality of life, also because of the preserved landscape, while Slovenians recognized opportunity for closeness and exchange with the other culture and country. As downsides, both acknowledged the potential and fear for the job market situation: the Austrians mentioned unfavourable economic conditions and insecurity, while the Slovenians were worried by the low salaries and illegal work presented in the region. Both also agreed that the region was remote and that the work opportunities in the region were poor which resulted in the high commuters share (Regional consulting Vienna, 2002).

\begin{tabular}{|l|l|l|}
\hline & Austria & Slovenia \\
\hline$;$ & $\begin{array}{l}\text { Openness to the neighbours } \\
\text { Possibilities for cheaper shopping } \\
\text { Landscape, quality of life }\end{array}$ & $\begin{array}{l}\text { Proximity to the border, opportunities for CB } \\
\text { co-operation } \\
\text { Possibilities for cheaper shopping } \\
\text { Work opportunities, better payment } \\
\text { Closeness to other culture, country }\end{array}$ \\
\hline$;$ & $\begin{array}{l}\text { Unfavourable economic conditions } \\
\text { Insecurity on job market, salaries } \\
\text { Remoteness of the area } \\
\text { Low work opportunities in the region (44\%) } \\
\text { High share of commuters 49\% }\end{array}$ & $\begin{array}{l}\text { Illegals, people seeking asylum } \\
\text { Remoteness, loneliness, political disregard } \\
\text { Job market, low salaries } \\
\text { Work opportunities in the region are low }(70 \%)\end{array}$ \\
\hline
\end{tabular}

Tab 2. Pros and cons of CBC region. (Regional consulting Vienna, 2002.)

\subsection{Job market expectations}

The most exposed in the future expectations was the job market to which positive and negative impacts of the EU were assigned as noticeable in the Table 3. This is a relevant question to the region with such a vivid history of working migrations, both of the migrant workers type (Sweden, Germany, Switzerland, Austria) or outmigration type (Zupančič, 2003, 2009), meaning that cross-border working migrations to Austria already existed at the time of accession. The Austrian apprehension of the EU was very positive stating that Slovenia as the new member would enable economic boom, increase exchange in the CBC area and foster the development of tourism. The later was also mentioned by Slovenians which set less 
ambitious goals like development of the region, lower unemployment and establishment of a free market. The negative impacts outnumbered the positive ones, especially because of the job market and economy problems such as high unemployment, lowering of the income, uncompetitive regions and above all as mentioned by Slovenians higher taxes and prices. Interestingly $40 \%$ of the Austrian respondents answered that the entering of Slovenia would not bring much to the region; such opinions were shared by $34 \%$ of Slovenians. $5 \%$ of Slovenians were of opinion that entering EU would have no impact on the job market.

The problem as seen by respondents of both sides was the low qualification level - on one side a result of the selection of traditional branches and professions and on the other side of the limited education options. Furthermore, several studies had predicted the inflow of the commuters from the new member countries to work in the low income branches which might have presented even higher unemployment risk for the local less qualified workers (Regional consulting Vienna, 2002).

\begin{tabular}{|c|c|c|}
\hline & Positive impacts & Negative impacts \\
\hline Austria & $\begin{array}{l}\text { Economic boom } \\
\text { Increased economic exchange with } \\
\text { Slovenia } \\
\text { Fostering the development of the } \\
\text { tourism }\end{array}$ & $\begin{array}{l}\text { Job market problems } \\
\text { Lowering of the income } \\
\text { No changes } \\
\text { Increase in crime }\end{array}$ \\
\hline Slovenia & $\begin{array}{l}\text { Free market, tourism } \\
\text { Development of the region } \\
\text { Lower unemployment }\end{array}$ & $\begin{array}{l}\text { Problems in economy, agriculture } \\
\text { Regions not competitive in EU } \\
\text { Poverty } \\
\text { Higher unemployment } \\
\text { Higher taxes, prices }\end{array}$ \\
\hline
\end{tabular}

Tab 3. Expected changes on the labour market. (Regional consulting Vienna, 2002.)

\subsection{Cultural landscape changes predictions}

The structural changes in economy and population have resulted also in enlargement of the agglomeration area. The landscape is influenced not only by physical changes caused by natural processes but also through social factors such as outmigration, high commuters mobility, high share of employment in primary sector, and diminished importance of tourism. The development of the cultural landscape is partially dependent on the growth of the Graz/Maribor central area and the selection of the functions settlements provide for inhabitants.

Landscape changes analysis was performed with the help of detailed maps analysis and thus could be reflected in the land use. The development of land use from 1821 to 2000 - in the Slovenian pre-accession period - showed that the agricultural land had significantly increased, e.g. fields had grown over the grassland. The crops structure had evolved with more corn and pumpkin production and less cereals like barley and potatoes. The production had become more intensive, the area of pastures, forests and orchards had decreased, while the amount of vineyards stayed the same. The corn production had been intensified in order to feed the pork and poultry. The pumpkin was important for the oil production which was geographically protected (Regional Consulting Vienna, 2002).

Similar trends had been acknowledged in Slovenia, because of melioration and waterworks the agricultural land had been intensified. After gaining the independence in 1991 the goal of agricultural policy was to increase the cattle production, however one should be aware of the ecological sensibility of the Mura plain because of the underground water location. Applying of the Common Agricultural Policy, shorter CAP, was not evaluated as problematic, neither significant changes were expected. Substantially more than from CAP the demographic and economic development had been influenced by the infrastructure construction (road, railway, water, sewage utilities) co-founded by development funds which further aggravated the commuting scale. Simplification of the procedures to gain the building permission had 
enlarged the investors' pressure on the land, and had to some extent consequently also decreased the agricultural area.

The changes that participants predicted for the then future period from 2000 to 2020 included prediction of prevalence of corn production, the increase in yield but decrease in the size of the agricultural area which simplified meant intensification of the agricultural production. On the other hand they were aware that due to the EU demands the agriculture would need to be ecologized and the most development opportunities would be found in agricultural niches, CBC projects and in tourism. Whether the built area was predicted to enlarge was unclear. The biggest expected change in the cultural landscape was the liberalisation of the work and property market which meant that the agriculture needed to adapt as well: new ways of production, approach to the farm management. The number of farms would decrease on one side, while the size on the other would enlarge. Some of the participants even argued no significant changes were expected in the agricultural land use. The participants in the survey were only partially able to judge how big the changes were really going to be because of the fact that in spatial terms AT-SI area had been pretty opened already before the EU accession (Pfefferkorn, 2005; Regional Consulting Vienna, 2002).

\section{Ten years after}

\subsection{The impact of entering EU on the selected areas}

In this section of the article the current situation in a selected member state and the case study region is elaborated in the framework of the survey results. Generally, most of the forecasted predictions have materialized to this date, the largest difference between the prognoses and nowadays is in the economic development. This is partially understandable because of the various factors that occurred in the meantime and could not be easily predicted in advance, e.g. global economic crisis that affected the (transition of) economy in a greater scale, the ways of transposing the EU legislation, including habitat directive, which installed additional barriers to the economy, construction of the motorway cross which on one side improved accessibility of the region but on the other also enabled easier commuting, thus a slow degradation of the role of Murska Sobota as the regional centre (Tropper, 2009; Zupančič, 2009).

While the tourism has been fostered in both countries, the industry on the other hand is not following this trend since companies have been closing down and only a certain amount of jobs is recuperated for with the small innovative companies' establishment. Therefore, their prediction of more industries located in the region did not happen. To which extent the economic situation of the area improved because of the EU funds is difficult to evaluate directly because of the above stated factors and also because of the special incentives the Slovenian government introduced to the region after textile industry Mura closure in 2009. In 2010 a special law was adopted by Slovenian government which granted the financial development support for the region for the period 2010-2015 (Zakon o razvojni podpori, 2009). With the funds of 33 million EUR the new jobs should be opened and the existing preserved, the basic infrastructure was tent to be built - additional financial sources granted - and the consequences of economic and financial crisis alleviated. So far, around 1.000 new jobs have been provided; however, mixed opinions are available on the efficiency of such solutions (Damijan, 2012). On the EU front it can be confirmed that the EU accession significantly increased inflow of the regional development funds and the standards of environmental protection. The latter was not directly argued by participants in the survey as potential change although they had put the nature and the environment high on their regional qualities list.

The strict environmental legislation of the EU such as for example nitrate directive have forced the state to introduce measures in favour of environment, e.g. installation of purifying plants, protection of the areas of high natural importance under Natura 2000, construction of sewage systems which were missing in this area and substantially also added to the quality of the landscape. Furthermore, the region has profited from the newly accessible funding opportunities, including European Regional Development Fund, European Social Fund, and especially important for this region, Common Agricultural Policy. These funds are available on the basis of different operational documents, so the local community Gornja Radgona and 
Cankova have been development-wise integrated in the Pomurje region which has so far prepared two regional development programmes (2002-2006, 2007-2013) and now is starting with the new one. In the strategic and implementation part which follows the analytical part the projects to be financed by the EU, state and other co-financing parties (municipalities, private investors) are listed. Relevant to the landscape topic are the three goals: resilient and business wise local communities and development of the partnership, the healthy environment for the health of population and progressing development all around the region (Regionalni razvojni program, 2007). In the period 2000-2006 altogether 83.5mio EUR were spent, of which $40 \%$ came from the region and the rest from the European (Interreg IIIA, Phare) or national funds. Projects which indirectly utilized the value of the landscape include construction of the new spa hotel, thematic and recreational paths (tourism), several activities for the agriculture like joint presentation on the markets, ecological agriculture, incubator for healthy food, environmental measures like improved water provision for the region, establishment of healthy community, promotion of the region as the land of healthy and friendly people and others. The projects directly relevant to the landscape which were categorized under "nature protection and preservation of cultural heritage" were not realized at all. In the municipality Gornja Radogona, three projects, financed through indirect regional impetus, related to the landscape quality improvement took place, hence the treatment facility, vine routes and tourist promotion of the settlement Negova.

From the cross-border aspect, however the most important programme is the CBC SloveniaAustria which covers the whole northern border of Slovenia and in Austria incorporates the Carynthia and Styria. Correspondingly to the EU funding period, the second programme is now running, called the Operational Programme Slovenia-Austria 2007-2013. In the period 2000-2006 the landscape was integrated into the Priority 3 "Sustained spatial development", more precisely under "Environment and Energy Management". The Municipality Cankova was participating in two projects: Preserving a habitat for endangered birds (89,939EUR) aimed at preservation of threatened habitats in agricultural land, e.g. old meadow orchards in the Goričko area, and the education of the meadow owners and the second project - a plan to manage the watershed of the Ledava river and the Ledavsko lake in which the Watershed area Radkersburg also participated. The common goal of this 170,311 EUR worth comprehensive project was to provide the plan for the $60 \mathrm{~km}^{2}$ area which will solve the problem of polluted water and its management and enabled preservation and sustainable development of natural resources. Two other projects of inspected municipalities were the COVE - Renewable Energy Sources Road (74,180 EUR) which established the promotion road of good practice in the use of renewables. The project linked existing energy road in Austria to the newly established locations in Slovenia. The project REGIO VITALIS should have improved the educational level and introduced new types of jobs by innovative approaches to the health tourism. To deliver the project, Regional Agency Mura, High school for tourism Radenci, Oststeiermark and Schulung Zentrum Fonhsdorf co-operated.

In the new CBC programme 2007-2013 74mio EUR were assigned for the SI-AT area. The projects which succeeded in several public calls can be altogether clustered in 86 dimensions of which 13 are related to the landscape and landscape changes. As seen in table 4, not all dimensions which could be as well considered objectives are covered with projects; the most projects are allocated in dimension aiming at improving the tourist services and in the protection and preservation of the cultural heritage, and in the group of integrated projects for urban and rural regeneration.

From the selected municipalities in this programme period only two out of four participate in any project related to the landscape change. The partners from municipality of Gornja Radgona are three, two participate in the project SKUPAJ, the other one in the project DRA-MUR-CI. In the first project partner from Bad Radkersburg is also presented, another one takes the part in the project TRILOC. Project SKUPAJ (Together) is the project which joins Bad Radkersburg and Gornja Radgona in order to deliver the joint urban and landscape development of Mura river bank which makes it directly relevant to the topic. The project is a continuation of the Interreg IIIA project which covered bilateral urban planning competition for both towns; this is now realization of the winning proposals for connecting the towns' nucleuses. Project, worth 
2mio EUR, started in year 2010 and will last for 36 months. It aims at raising the awareness about the life along the river, landscape and architectural creation of the new public spaces or their renewal, redefinition of the public space in the towns and promenade along the Mura river. Besides improved connectivity of the locals from both side of the border, one of the results will also be the list of the future design development projects for the new recreational areas on the both side of the border (Project Together, 2012) which correspond to the exact objectives of the InterregIIIA programme.

\begin{tabular}{|l|l|}
\hline Dimension title & Allocated projects \\
\hline Cycle tracks & I \\
\hline $\begin{array}{l}\text { Energy efficiency, co-generation, energy } \\
\text { management }\end{array}$ & MOVE, Efficient Effective Smart, PEMURES \\
\hline $\begin{array}{l}\text { Management and distribution of water (drink } \\
\text { water) }\end{array}$ & MURMAN \\
\hline Integrated prevention and pollution control & PMINTER \\
\hline $\begin{array}{l}\text { Promotion of biodiversity and nature } \\
\text { protection (including Natura 2000) }\end{array}$ & karawanks@future.eu, AMC PROMO BID, ALPA \\
\hline $\begin{array}{l}\text { Other measures to preserve the } \\
\text { environment and prevent risks }\end{array}$ & HEALTH, DRAMURCI, GOAL, NH-WF \\
\hline Promotion of natural assets & GEOPARK \\
\hline $\begin{array}{l}\text { Protection and development of natural } \\
\text { heritage }\end{array}$ & Nature experience, Karafish \\
\hline $\begin{array}{l}\text { Other assistance to improve tourist services } \\
\text { Hiking\&biking, VINO COOL, REACT, Adventure } \\
\text { PEtzen/Peca, Pilgrimage Europe SI-AT, REGIO } \\
\text { VITALIS, Family Centers, Brod na Muri, AIN-DJN }\end{array}$ \\
\hline $\begin{array}{l}\text { Protection and preservation of the cultural } \\
\text { heritage }\end{array}$ & $\begin{array}{l}\text { Spomeniki/Denkmäler, CULTH:EX CAR-GOR, } \\
\text { CAJ/TEE, DUO Kunsthandwerk, MINDOC, Matriken } \\
\text { Digital, FLU-LED, Inter-Arch Steiermark }\end{array}$ \\
\hline Development of cultural infrastructure & TourKult \\
\hline $\begin{array}{l}\text { Other assistance to improve cultural } \\
\text { services }\end{array}$ & Grenzenlos/Brezmejnost, SOSED/NACHBAR \\
\hline $\begin{array}{l}\text { Integrated projects for urban and rural } \\
\text { regeneration }\end{array}$ & $\begin{array}{l}\text { City Cooperation, SKUPAJ, City Impulses, CITY } \\
\text { NETWORK GRAZ-MARIBOR }\end{array}$ \\
\hline
\end{tabular}

Tab 4. Projects, financed by 2007-2013 CBC, aiming at landscape development. (CBC SI-AT, 2012b)

\subsection{Changes in the job market}

One of the biggest concerns of survey participants was about the job market change after the accession. While Slovenians were in favour of these changes, the Austrians feared that their salaries would be threatened or their jobs would be questioned. Especially, this might be relevant because of the economic condition in Pomurje region which is not only one of the most deprived Slovenian regions (BDP per capita 11,445 EUR vs. national 17,379 EUR, 2010) but has also suffered a lot from the industrial transformation: reduction of the textile industry, closure of some small factories that employ low educated working force. More effort is needed for the transformation of economy also because of a specific employment structure, e.g. high number of employment in the agriculture $(7.7 \%)$, tourism $(5.4 \%)$ and health and service $(7.6 \%)$. The significant change in last 10 years has been the decrease of employment in the secondary sector and the increase of the unemployment. The unemployment level has been fluctuating, however in the last 5-year period also as a crisis consequence it augmented in both Slovenian municipalities (Cankova - 19\%; Gornja Radgona - 14\%) as well as on the national level (12\%). The regional unemployment level was high at the time of the accession and has not changed since then. As argued, positive changes have been brought in by the regional specific law (2009), although it did not manage to spur the replacement of the closed down number of jobs.

The most common indicator to illustrate the changes on job market in cross-border area is the cross-border work migration and commuting rate, although here it should be taken into 
account that this commuting to some extent existed already before the border opening (Zupančič, 2009). The comparison of the work migration rate between 2001 and 2011 indicates that the index of working migration (ratio between the people who live and work in municipality and the people who live in the municipality but work elsewhere) increased moderately in Cankova (from 44 to 49) while in Gornja Radgona numbers are higher (from 106 to 138). While the later can be classified as working municipality, the smaller is prevailingly residential. The unemployment rate, unavailability of the jobs, e.g. in Slovenia the job availability from year 2011 to 2012 went down 12\%, and the higher salaries in Austria resulted in increased daily commuters phenomenon to the neighbouring Austrian towns.

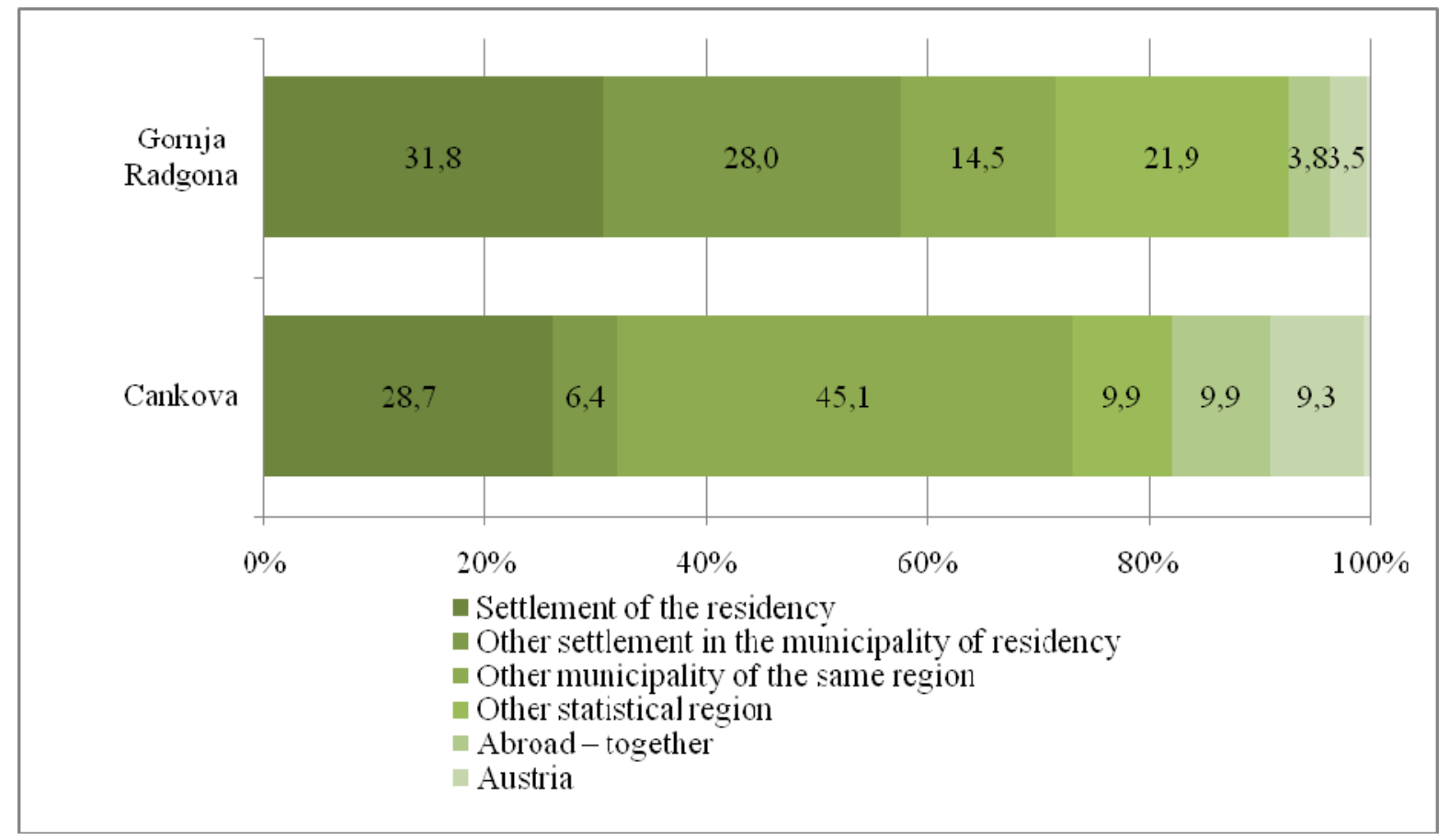

Fig 2. The share of employment location for the residents of the selected municipality in year 2011. (SORS, 2012b).

The phenomenon is not directly monitored, but some data have been provided by the national statistical office. As figure 2 shows around $10 \%$ of border working population is employed in Austria, else the municipalities also indicate high daily commuting to other Slovenian municipalities in the neighbourhood. This might be result of the small size of the municipalities (up to $20 \mathrm{~km}^{2}$ or so) and thus the inability to find the job inside your own municipality. In regards to the job market, the income tax policy has recently become the news' topic. The commuters who work in Austria have higher income tax relieves in Austria than in Slovenia therefore they needed to pay in the difference in Slovenia which with the net salary of 800 to 1,200 EUR meant around two salaries. In 2007 the regulation was adopted by which they were relieved from paying the income tax in Slovenia, however, the recent economic crisis brought the topic and potential introduction of the smaller relief back on the plate (Celin, 2012; Damijan, 2012).

Incomplete data as reported by the Statistical Office of the Republic of Slovenia can be supplemented with the migration information, although, again no precise information for the targeted localities are available. The figure 3 illustrates that after the accession the number of emigrants to abroad was high (5.7 per 1000 population), while the migration trend between municipalities changed from negative to positive one. 


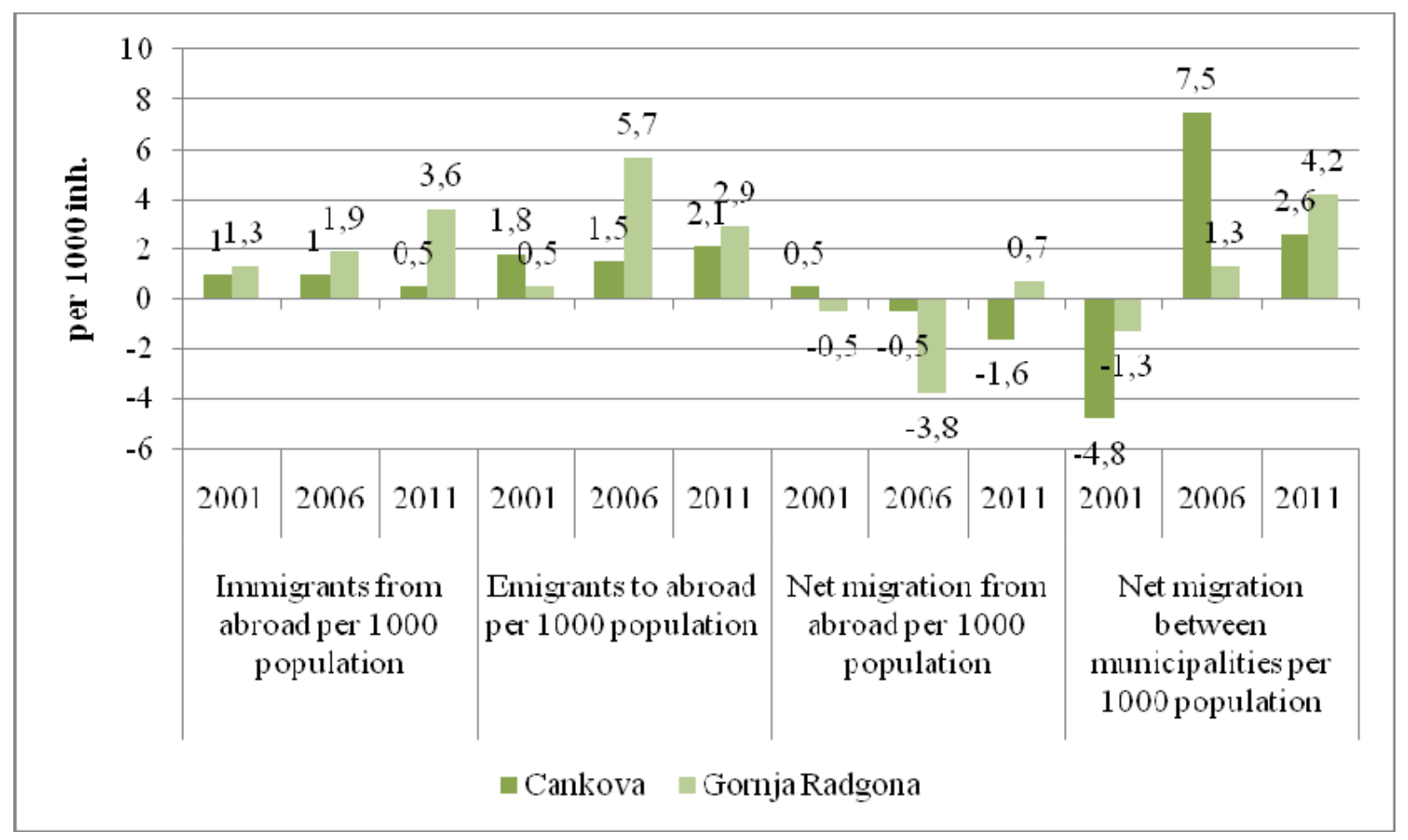

Fig 3. Migration change of population, Cankova and Gornja Radgona in selected years. (SORS, 2012a)

\subsection{Cultural landscape changes due to the entering of EU}

Although not expected to such extent and not only connected to the cross-border area, the EU accession significantly influenced the agriculture sector, thus also the landscape in selected region. The figure 4 shows interesting trend in the land use which is quite contrary to the national figures. This can be partially argued by the distinctive agricultural orientation of region in comparison to other Slovenian regions. The size of the arable land has increased, while on the other side the grassland and forest have decreased.

The crops type in production is usually argued to be the consequence of the European CAP policy, however the market demand steers it as well. In both municipalities the crop production has decreased, except for the barley, maize and potatoes, then increase is evident for the industrial crops and vegetables (due to the municipalities' similarities only charts for Gornja Radgona are presented). The induced closure of the sugar plant in Ormož has substantially changed land use since sugar beet production has been replaced with the oil rape needed for the bio fuel production, but less profitable for the farmers. In addition, scientists share different opinions on the rape as a crop because it requires a vast amount of pesticides and fertilizers, thereby consuming energy and adversely affecting the ground water. Here production is connected to the new biodiesel factory in Lendava of which construction started in 2007 and should annually produce 60,000 tonnes of biodiesel. As a contradiction to that University of Maribor prepared the study for reopening of the sugar plant for which they would buy the previous factory location with the entire infrastructure and with 133 million EU investment restart the production. To cover the Slovenian needs, 40 tonnes of the sugar beet should grow on approximately 15,000 ha of land, if not sufficient in Slovenia, Croatian and Hungarian farmers would come in as previously (Milošič, 2013).

As predicted in the research, the farmers are looking for the selling niches, hence intensively introduce the bio production and experiment with the new crops. One of such examples is the production of the industrial hemp for which the producers are still trying to change the regulation which now limits the growth. The plant is not only used for medical and dietary purposes, just cross-border (Heiligenkreuz) they built the plant Biolnnova which would use hemp for biofuel production. Untraditional is also the production of orchids, company Ocean Orchids, which started its business in 2003 on the basis of well established European connections in the $\mathrm{CBC}$ area with Hungary and Croatia and of which production covers 
3 hectares and yield 1,200,000 plants per year to import into the neighbouring countries of Hungary, Croatia, Italy and others (Ocean Orchids, 2013).

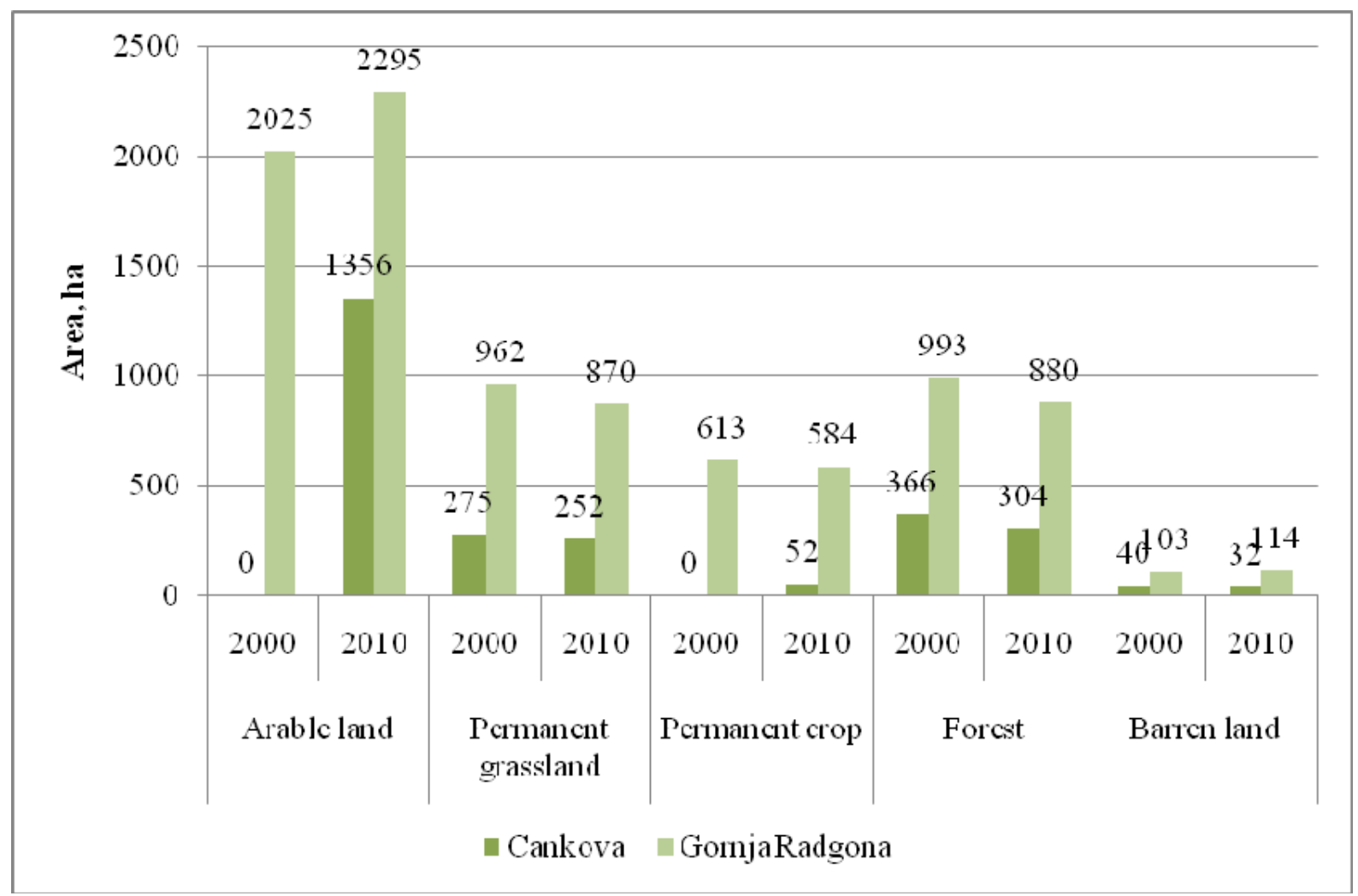

Fig 4. Total agricultural area by land use type, 2000 and 2010. (SORS, 2012a)

Additional changes to the landscape can be caused by agriculture also by the type of the cattle production, especially when the free pasture is financially stimulated. The statistics shows that the number of almost all holdings besides the small cattle ones is decreasing which can be argued that the pressure on the land from the cattle has been changed, whether the farms have been restructured or they have been closed down.
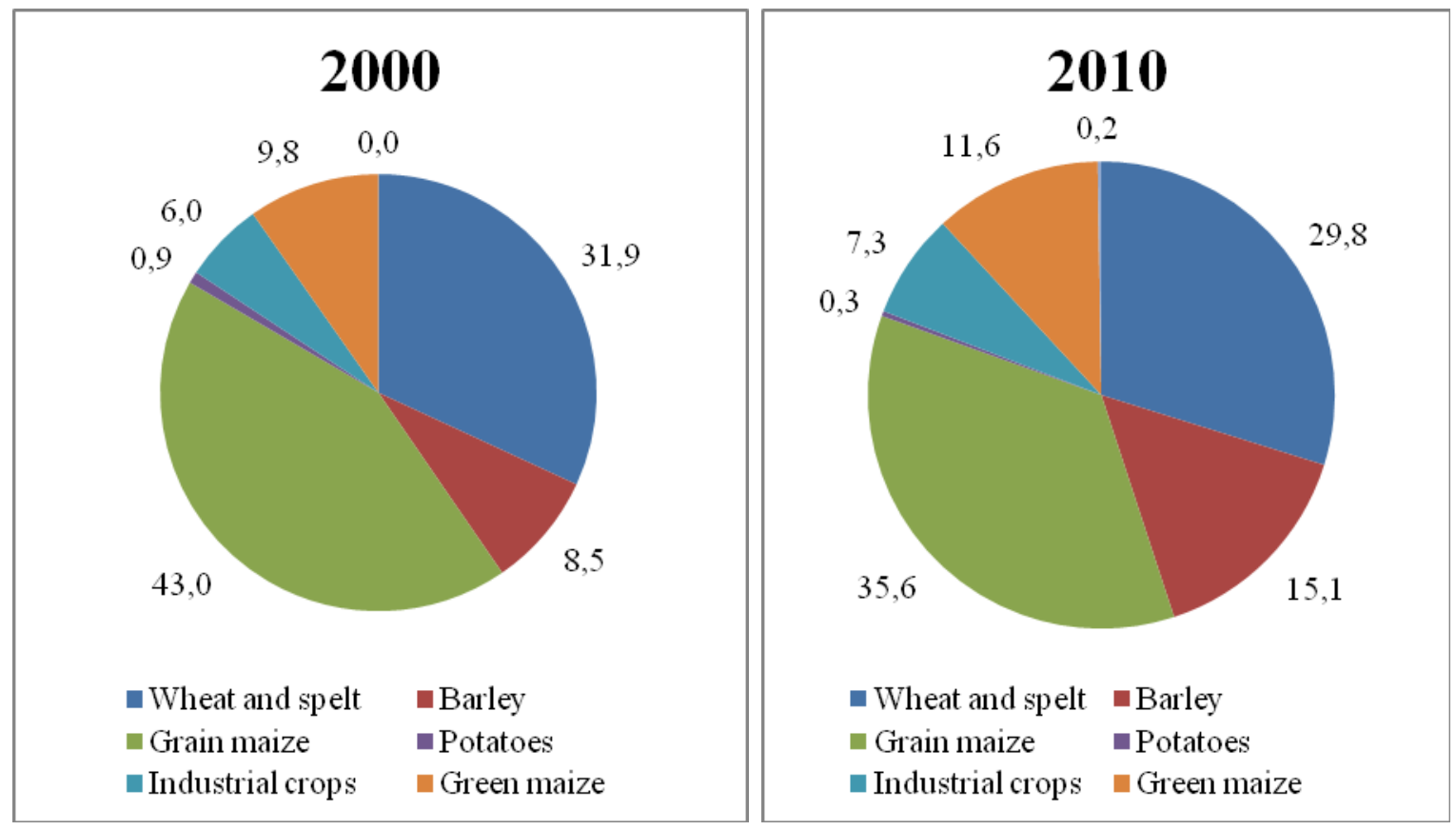

Fig 5a, 5b. Changes in the type of crop production in Gornja Radgona, 2000 and 2010. (SORS, 2012a) 
While the changes in agricultural production usually induce direct changes in the landscape outlook, landscape changes can be as well result of an individual project such as for example construction of the cycling paths or marking the tourists paths. The tourist projects are sometimes dependent on the money that derives from the natural protection funds or programmes, etc. Natura 2000. From the projects, financed by CBC programme and through RDP the positive impacts are improvements of the environment quality, upgraded infrastructure including utilities, raised awareness about ecology and importance of the high quality of life, introduced for example through new public space like pathways along the Mura river.

\section{Conclusion}

The analysis of the data which mainly focused on Slovenia showed that the landscape in the selected new member state has been significantly influenced by the EU accession thus the major hypothesis that socio-economic changes influenced by regional, sectoral and EU policy reflect in the landscape changes can be confirmed. These alterations are illustrated by the change in the land use, crops, spatial organization, new infrastructure, newly utilized resources and the new spatial qualities in the towns. Factors inducing the changes are several and include the transposition and implementation of the EU legislation, e.g. environmental protection legislation, introduction of the financial incentives, e.g. cohesion funds, opening of the borders and the market which enables free flow of the people and goods and national funds insinuated to catch up the other, more advanced regions. Similar changes have been noticed in other new member states like in Poland, Czech Republic on the border with Germany (Ladysz, 2006; Krätke, 2002). While the list of factors mainly focus on the EU-induced factors, the list of internal factors is important as well, especially the capacity and institutional preconditions which lagging behind regions possess only to a certain extent. EU related is the adoption of European Landscape Convention which demands from the signatories to respect the landscape. Similar to that are goals listed in the Slovenian spatial development policy, e.g. protection of the landscape heritage and its valorization for the purpose of improved quality of life.

What differs the cross-border area from the rest of the territory, is the perception and specific identity of the place, previously demarked by the border, thus artificially divided which represents the irrational factors of the change. This in Convention falls under the category of EU and regional identity empowerment which can be argued by the fact that the EU allows for a more global perception of the territory but as well calls for the protection of the local traditions and their integration into the larger picture. The job market was one of the topics, addressed in the survey in which fears and expectations were expressed. In line with the EU average (Van Houtum, Van der Velde, 2004) people's expectations of job and living mobility are much higher than actually realized which in our case was proved by the data analysis. Though the percentage of the work commuters (3.5 or 9.3\%) is substantially higher than the EU average of $0.2 \%$ in 2004 (Van Houtum, Van der Velde, 2004). It seems that the presumption about the physical nearness but mental farness of the job market in SI-AT case is not valid which might be because of a joint history and previous openness of the border and the higher Austrian salaries which present the important pull factor for Slovenian workers. Those similar to the Czech ones live at home but commute to work. As argued by Holly et al. (2003) it is unlikely that the commuting flow would go in other direction because of the language barrier and also fears about competitiveness, expressed in the survey. In this case the mental distance as defined by Van Houtumn (1998) obstructs balanced commuting flow. Further factors pulling back the potential bigger profit from the CBC co-operation are as mentioned by the project IQ train (2013) the too lower internationalization of the small businesses, only a little cross-border co-operation of industrial networks and clusters or between the technological parks and lack of professional capacity in the production processes.

The investigated municipalities on both sides of the border have several common characteristics: tourism as important economic activity, small size central town, low education level of population and influence by the larger cities in the vicinity but due to the data limitation more attention was brought to the landscape changes in Slovenian part of the area. These changes proved to be the continuous effort of the CBC programme as already evaluation of the 2000-2006 programme showed with high budgets on large, medium-sized or small areas 
had a more visible and physical impact on territorial development than programmes with medium-sized or small budgets intervening in relatively large areas (Panteia, 2010). Example of such environmentally driven project is the project SKUPAJ which has brought several new landscape qualities into the region. In addition to such, often soft measures, the infrastructure construction represents above the most important new landscape feature, consequently one could argue that by newly built connections also places with renewed identity are created, as are the examples of Gornja Radgona and Bad Radkersburg town centres. This is in line with Cosgrove (1984) who argued that every socio-economic formation, in this case these two towns, tries to create its own landscape by wiping off the uses and symbolic values of previous formations and replacing them with the new ones which occurred after the accession.

Not only because of the EU but also due to the new social paradigms, the landscape has been largely influenced by the concept of the sustainability. In regard to the landscape this has brought new types of the agricultural production, e.g. orchids production, downsizing the insensitivity of the agricultural production, increased importance of supplied green and recreational areas and new types of tourism, e.g. eco tourism. The need for applying the sustainability into the new investments can be illustrated by the fact of year 2005 expenditure for the environment by which the Pomurje region was first among Slovenian region, financing the basic utilities, such as water and waste disposal (Vintar Mally et al., 2009). By inspecting the factors inducing change two-side relationship has been identified: on one side, the policy as for example the EU Common Agricultural Policy has induced the landscape change (Rodewald, 2004; Ries, 2010; Martinez-Casasnovas et al. 2010), and on the other, the improved quality of life because of the beautified landscape has indirectly shaped minds, ideas, emotions and identities to introduce continuous projects which aim at creating the unified cross-border landscape like in the towns Gornja Radgona and Cankova (Moore, Whelan, 2007). These findings are also in line with the evaluation of the 2000-2006 programme which showed that $C B C$ is especially beneficial for medium- or small size local communities in which physical investments are important drivers for generating territorial development impact, so is the newly established "soft co-operation", e.g. the joint elaboration of studies, new techniques etc., enabled by the programme. Thus if the neighbouring $\mathrm{CBC}$ municipalities continue here observed work and built on the already performed projects aimed at enhancing the sustainability of the landscape development we can in long term expect new-sprung landscape based more on common landscape feature than on political demarcations. According to Tropper (2009) one of the biggest problems is the lack of political support for the establishment of more firm crossborder region. For now the informal meetings of the mayors from the affected regions and mostly individual institutional co-operation in the CBC projects is not a ground enough for such an establishment. As Urbanc et al. (2004) argued this transformation may take certain time to be absorbed by the people of the region as well. Until then it can be generally concluded that EU accession can be perceived as positive, however we should also be aware of the fact that EU co-operation can only spur spatially integrated sustainable development to a certain level (Ladysz, 2006) and that in the process of members' adaptation and transposition of the EU regulation they might lose in the negotiation for tits and tats.

\section{Acknowledgements}

This article is partially based on the results of the research Opportunities and risks for sustainable development of cultural landscape in the case of EU expansion to the East performed by Regional Consulting ZT GmbH, E.C.O. Institut für Ökologie, L\&R Sozialforschung and Urban Planning Institute of the Republic of Slovenia and financed by the Bundesministerium für Bildung, Wissenschaft und Kultur, Wien. The project was conducted between 2000 and 2002. The results of the mentioned research were used for this article with the permission of Slovenian contributors to it.

Special thanks goes to Jörn Harfst, University Graz, Institute of Geography and Regional Sciences for his fruitful feedback on the initial version of the article. The publishing of the paper is supported by the Visegrad Fund, project Nr. 11220149 "Borders and Borderlands within the Central Europe". 
References

[1] Antrop M. (1998). Landscape change; plan or chaos? Landscape Urban Planning 41, 155161. Doi: 10.1016/S0169-2046(98)00068-1.

[2] Antrop M. (2005). Why landscapes of the past are important for the future. Landscape and Urban Planning, 70 (1-2), 21-34. Doi: 10.1016/j.landurbplan.2003.10.002.

[3] CBC SI-AT (2012a). Map of the area. Retrieved 10. 12. 2012 from: http://www.siat.eu/start_en/.

[4] CBC SI-AT (2012b). Programme and projects dimensions for period 2007-2013. Data provided by the Joint Technical Secretariat OP SI-AT.

[5] CBC SI-AT (2012c). Programme Slovenia-Austria. Retrieved at 10.12.2012 from: http://www.si-at.eu/start_sl/.

[6] Celin M. (2012). Delovni migranti davčne olajšave ne dajo. DELO, 20. 10. 2012. Retrieved 5. 1. 2013 from: http://www.delo.si/novice/slovenija/delovni-migranti-davcne-olajsave-nedajo.html.

[7] Commission of European Communities (1994). Cross-Border Cooperation. Luxemburg: Commission of the European Communities Directorate General for Regional Policies.

[8] Commission of the European Communities (1999). European Spatial Development Perspective - Towards Balanced and Sustainable Development of the Territory of the EU Committee on Spatial Development. Brussels: CEC.

[9] Commission of the European Communities. (2012). Fifth Report on Economic, Social and Territorial Cohesion. Retrieved 10.12 .12012 from: http://ec.europa.eu/regional_policy/sources/docoffic/official/reports/cohesion5/index_en.cfm

[10] Cosgrove, E. D. (1984). Social Formation and Symbolic Landscape. Madison: University of Wisconsin Press.

[11] Council of Europe (2000). European Landscape Convention. Retrieved 2. 4. 2013 from: http://www.coe.int/t/dg4/cultureheritage/heritage/Landscape/default_en.asp.

[12] Damijan J. P. (2012). Davčna kratkovidnost in brezposelnost v Pomurju. Finance, 15. 11. 2012.

[13] Das Mur-Projekt (Steiermark - Slowenien) (2006). In Jungmeier, M., Pichler-Koban, C., Drapela, J. (eds.), Grenzlandschaft EU-Erweiterung und Landschaftsentwicklung. Wien: Bundeministerium für Bildung Wissenschaft und Kultur.

[14] ESPON (2006). Territory matters for competitiveness and cohesion. Facets of regional diversity and potentials in Europe, ESPON Synthesis Report III, results by autumn 2006. Luxembourg: ESPON.

[15] ESPON (2007). Cross-Border Cooperation - Cross-Thematic Study of INTERREG and ESPON. INTERACT, Luxembourg: ESPON.

[16] Gonin, P. (1994). Régions frontalières et développement endogène: de nouveaux territoires en construction au sein de l'Union Européenne. Hommes des Terres du Nord, 2$3,61-70$. 
[17] Holly W., Nekvapil J., Scherm I. \& Tišerová, P. (2003). Unequal neighbours: coping with asymmetries. Journal of Ethnic and Migration Studies, 29(5), 819-834. Doi: 10.1080/1369183032000149587.

[18] Huber, P. (2003). On the Determinants of Cross-border Cooperation of Austrian Firms with Central and Eastern European Partners. Regional Studies, 37, 947-955.

[19] Keisteri T. (1990). The study of change in cultural landscapes. Fennia, 168(1), 31-115.

[20] Klemenčič, V. (1992). Wandlungstendenzen im ländlichen Raum Sloweniens. In: Ruppert, K. (ed.) Ländliche Räume im Umbruch - Chancen des Strukturwandels, Kallmünz/Regensburg: M. Lassleben, 99-110.

[21] Krätke S. (2002). The Regional Impact of EU Eastern Enlargement: A View from Germany. European Planning Studies, 10(5), 651-664. Doi: 10.1080/09654310220145378.

[22] Ladysz J. (2006). Chosen aspects of sustainable development on the Polish, Czech and German borderland. GeoJournal, 67, 1-7. Doi: 10.1007/s10708-006-9002-7.

[23] Landesstatistik Steiermark (2013). Statistical data on municipalities Bad Radkersburg and Feldbach. Retrieved 5. 1. 2013 from Landesstatistik.steiermark.at.

[24] Martínez-Casasnovas J. A, Concepción Ramos M. \& Cots-Folch R. (2010). Influence of the EU CAP on terrain morphology and vineyard cultivation in the Priorat region of NE Spain. Land use Policy, 27(1), 11-21. Doi: 10.1016/j.landusepol.2008.01.009.

[25] Medeiros E. (2009). Cross-border Cooperation in EU Regional Policy: a fair deal? Lisboa: Universidade de Lisboa.

[26] Milošič F. (2013). Gradnja nove "cukerce" bi se Ormožu splačala. DELO, 26.01.2013.

[27] Ministry of the Environment, Spatial Planning and Energy (2004). Spatial Development Strategy of Slovenia. Ljubljana, Ministry of the Environment, Spatial Planning and Energy.

[28] Moore N. \& Whelan Y. (2007). Heritage, Memory and the Politics of Identity. New Perspectives on the Cultural Landscape. Aldershot: Ashgate.

[29] Naveh Z. (2000). What is holistic landscape ecology? Landscape Urban Planning, 50, 7-26.

[30] Ocean Orchids (2013). Information about the company. Retrieved 6.1.2013 from http://www.oceanorchids.si/si/index.php.

[31] Palang H., Alumäe H. \& Mander U. (2000). Holistic aspects in landscape development: a scenario approach. Landscape and Urban Planning, 50, 85-94. Doi: 10.1016/S01692046(00)00081-5.

[32] Panteia (2010). INTERREG III Community Initiative (2000-2006) Ex-Post Evaluation. Final Report. Zoetermeer: Panteia.

[33] Perkmann M. (2003). Cross-border regions in Europe: Significance and drivers of regional cross-border co-operation. European Urban and Regional Studies. 10(2): 153-171. Doi: 10.1177/0969776403010002004.

[34] Pfefferkorn, W. (2005). Skupaj do novih bregov. Dunaj: zvezno ministrstvo Republike Avstrije za izobraževanje, znanost in kulturo.

[35] Potočnik I. (2001). Geographical aspect of rural area: Transformation in Slovenia. Bulletin de la Societe geographique de Liege, 41, 69-76.

[36] Project IQ- train (2013). Cilj 3 - čezmejno sodelovanje priročnik za nosilce projektov 20072013. Retrieved 1.4. 2013 from: http://www.iq-train.net/handbook/at_si/si/atsi_op_3_si.htm.

[37] Project Together (2012). Retrieved 11.12. 2012 from: http://www.poragr.si/projekti_det.asp?id=1382.

[38] Raich S. (1995). Grenzüberschreitende und interregionale Zusammenarbeit in einem 'Europa der Regionen'. Dargestellt anhand der Fallbeispiele Großregion Saar-Lor-Lux, EUREGIO und 'Vier Motoren für Europa'. Baden-Baden: Nomos. 
[39] Regional consulting Vienna (2002). EU-Osterweiterung: Chancen und Risiken fuer eine nachhaltige Kulturlandschaftsentwicklung am Beispiel der steirisch-slowenischen Grenzregion. Endbericht. Wien, Klagenfurt: Regional consulting Vienna, Institut fuer Oekologie, L\&R Sozialforschung, Urbanistični inštitut Republike Slovenije, BM:BWK.

[40] Regionalni razvojni program Pomurske regije 2007-2013. (2007). Murska Sobota: Regionalna razvojna agencija Mura d.o.o.

[41] Ries J. B. (2010). Methodologies for soil erosion and land degradation assessment in Mediterraneantype ecosystems. Land Degradation and Development, 21, 2, 171-187.

[42] Rodewald R. (2004). La explotación agrícola en función de la protección del Medioambiente. Fundación Suiza para la tutela del paisaje. I Simposio Hispano-Suizo: La integración Social de los Espacios Naturales Protegidos. MiraSuiza-JCyL 191-193.

[43] Schabhüser B. (1993). Grenzregionen in Europa. Informationen zur Raumentwicklung, 9, 10, 655-68.

[44] Schmitt-Egner P. (1998). "Grenzüberschreitende Zusammenarbeit" in Europa als Gegenstand.

[45] Wissenschaftlicher Forschung und Strategie transnationaler Praxis. Anmerkungen zur Theorie, Empirie und Praxis des transnationalen Regionalismus. In: Brunn G. \& SchmittEgner P. (eds). Grenzüberschreitende Zusammenarbeit in Europa: Theorie - Empirie Praxis. Baden-Baden: Nomos. pp. 27-77.

[46] Spatial Planning Act (2007). National Gazzette of the Republic of Slovenia, 33/2007.

[47] Statistics Austria (2013). Statistical data on Austria. Retrieved 5.1.2013 from: http://www.statistik.at/web_en/.

[48] Statistical Office of the Republic of Slovenia (2012a). Statistical data on municipalities Cankova, Gornja Radgona. Retrieved 5.1.2013 from: http://pxweb.stat.si/pxweb/Dialog/statfile2.asp.

[49] Statistical Office of the Republic of Slovenia (2012b). Statistical data on working migrants. Ljubljana: Statistical Office of the Republic of Slovenia.

[50] Tropper A. (2009). Die Staatsgrenze als raumprägender Faktor unter besonderer Berücksichtigung der steirisch-slowenischen Grenze. [Diploma thesis]. Graz: KarlFranzens-Universität.

[51] Urbanc M., Printsmann A., Palang H., Skowronek E., Woloszyn W. \& Konkoly Gyuró, E. (2004). Comprehension of rapidly transforming landscapes of Central and Eastern Europe in the $20^{\text {th }}$ century. Acta Geographica Slovenica 44(2), 101-131. Doi: 10.3986/AGS44204.

[52] Van Houtum H. (1998). The Development of Cross-Border Economic Relations. Amsterdam: Thela Thesis Publishers.

[53] Van Houtum H. \& Van der Velde M. (2004). The power of cross-border labour market immobility. Tijdschrift voor Economische en Sociale Geografie, 91(1), 100-107.

[54] Vintar Mally K. et al. (2009). Zagate trajnostnega razvoja v Pomurju. In: Kikec T.,ed., Pomurje: trajnostni regionalni razvoj ob reki Muri: zbornik povzetkov / 20. zborovanje slovenskih geografov. Ljutomer - Murska Sobota, 26. - 28. marec 2009.

[55] Zakon o razvojni podpori pomurski regiji v obdobju 2010-2015 (ZRPPR1015) (2009). National Gazzette of the Republic of Slovenia, 87/2009.

[56] Zupančič J. (2003). Crossborder Daily Labor Migrations in the Slovene Border Regions. Razprave in Gradivo, 43, 68-111.

[57] Zupančič J. (2009). Ob etičnem in državnem robu na slovenskem vzhodu. In: Kikec T. (ed.), Pomurje: trajnostni regionalni razvoj ob reki Muri: zbornik povzetkov / 20. zborovanje slovenskih geografov. Ljutomer - Murska Sobota, 26. - 28. marec 2009. 